\title{
BioLink
}

Jurnal Biologi Lingkungan, Industri, Kesehatan

\section{THE POTENTIAL OF NGOKILO LEAVES EXTRACT (STACHYTARPHETA MUTABILIS. VAHL) AS A LOWERING OF BLOOD GLUCOSE LEVELS OF WHITE MICE (RATTUS NORVEGICUS)}

\author{
Mimatun Nasihah* \\ Program Study Environmental Health, Faculty of Health Sciences, Universitas Islam \\ Lamongan, Indonesia
}

Submited : 16-06-2020; Reviewed :21-07-2020; Accepted : 18-12-2020

*Corresponding author: E-mail : mima@unisla.ac.id

\begin{abstract}
Diabetes is a disease, in which the body cannot produce enough insulin so that there is excess sugar in the blood which becomes toxic to the body. Ngokilo plants are believed to be able to lower blood sugar levels because of the antioxidants and polyphenols contained therein. The objective of this study was to determine the potential of the ethanol extract of Ngokilo leaves (Stachytarpheta mutabilis, Vahl) as a lowering blood glucose levels in white mice(Rattus norvegicus). The tests were carried out by an experimental method using Swiss Webster male mice (Rattus norvegicus) aged 2-3 months with a body west of 30-40 grams as test animals. This study used four dosage ratios of ngokilo leaf extract, namely 1:20:40:60 and control used aquadest. The results showed that the ethanol extract of Ngokilo leaves had an $F$ value of 27.033> F Table 2.60. It indicates that the independent variable (the difference in the concentration of ethanol extract of Ngokilo leaves) was proven to have a significant effect on the dependent variable (blood sugar levels).
\end{abstract}

Keywords: Diabetes mellitus; Ethanol extract; Ngokilo leaves

How to Cite: Nasihah, M. (2021). The Potential of Ngokilo Leaves Extract (Stachytarpheta Mutabilis, Vahl) as a Lowering Blood Glucose Levels of White Mice (Rattus Norvegicus), BioLink: Jurnal Biologi Lingkungan, Industri dan Kesehatan, Vol.7 (2): Hal. 204-214 


\section{INTRODUCTION}

Diabetes mellitus (DM) is a disease characterized by hyperglycemia and disorders of carbohydrate, fat and protein metabolism which are associated with absolute or relative deficiency of insulin activity and/or secretion (Forouzanfar et al., 2016). Diabetes mellitus is familiarly called the silent killer because DM can attack all organs of the body and cause various complaints. Diseases that will arise due to DM include visual impairment, cataracts, heart disease, kidney disease, sexual impotence, wounds that are difficult to improve and gangrene, lower respiratory tract infections, blood vessel disorders, stroke and others. Not surprisingly, DM sufferers who have severely amputated their body parts due to decay (Trisnawati, 2013).

Diabetes mellitus is a disease that has a serious impact on human health (Rahmawati et al., 2014). Diabetes is a metabolic disorder of glucose distribution by the body (Rohilla \& Ali, 2012). Diabetics are characterized by insulin that is not produced in the appropriate amount or the body is unable to use insulin effectively, as a result the blood sugar levels excess (Sangala et al, 2011). The lack of insulin activity causes the failure of glucose transport from plasma to cells (Hasanah et al., 2017). Glucose that is absorbed during the meals is not metabolized at a

reasonable rate so that it collects in the blood (hyperglycemia) and is excreted into the urine (glycusoria) resulting in osmotic diuresis and an impact on increased urinary production (polyuria)(Agung et al., 2017). In addition, abnormalities in glucose metabolism as a result of the lack of insulin activity also result in loss of fluids and trigger thirst (polydipsia) (Dewi, 2009).

Diabetes mellitus can lead to serious complications, such as hypoglycemia, which is a condition in which blood sugar levels drop dramatically due to too much insulin in the body, these symptoms include blurred vision, fast heartbeat, headaches, trembling, cold sweat, and dizziness. Diabetic ketosiadosis (KAD) is a medical emergency situation as a result of a very high increase in blood sugar content, it occurs when the body cannot use glucose as a fuel source, as a result the body processes fat and produces ketones as a source of energy. It can lead to accumulation of dangerous acids in the blood resulting in loss of body fluids, coma, shortness of breath, and death. Hyperosmolar hyperglycemic state (HHS), occurs as a result of a very high spike in blood sugar levels of a specific duration. Symptoms are characterized by acute metabolic disorders characterized by hyperglycemia, hyperosmolarity, and loss of body fluids without ketoacidos (Zamri, 2019). 
Uncontrolled diabetes can also lead to impact of diabetes, the patient's feet are at other serious complications, namely: 1). risk for easy injury and infection as a result Disorders of the eye (diabetic retinopathy), of gangrene and diabetic ulcers. 7). damage to the blood vessels in the retina Cardiovascular disease, high blood sugar and the potential to cause blindness in the levels can cause damage to blood vessels in eye. 2). Damage to the blood vessels in the eye caused by diabetes also increases the risk of visual problems, such as cataracts and glaucoma. 3). Kidney damage (diabetic nephropathy) can lead to kidney failure, moreover, it can end in death if not treated properly, the patient is obliged to carry out regular dialysis or kidney transplantation. 4). Nerve damage (diabetic neuropathy), high blood sugar in the blood can interfere with blood vessels and nerves in the body, especially in the legs, it occurs when the nerves are damaged either by direct impact of high blood sugar or because blood flow to the nerves decreases. The damaged nerves will cause sensory disturbances such as tingling, numbness, or pain, and can affect the digestive tract and cause gastroparesis, such as nausea, vomiting, and feeling full when eating. 5). In men, complications of diabetes mellitus can cause erectile dysfunction / impotence. 6). Germs and fungi will be very easy to reproduce in diabetics especially complications of diabetes mellitus can cause erectile dysfunction / impotence. 6). Germs and fungi will be very easy to reproduce in diabetics especially when the self healing ability decreases, due to the the body, it can cause the disruption of blood circulation in all bodies as well as in the heart. The complication of diabetes mellitus that affect the heart and blood vessels include heart disease, stroke, heart attack, and atherosclerosis. 8). The number of people with diabetes mellitus is increasing every year, it is estimated that in 2045 people with diabetes will reach 629 million people. This figure is sourced from a report by the International Diabetes Federation (IDF) in 2015 which said that the number of diabetes sufferers was 415 millions, in 2017 it was 425 millions. In Indonesia itself, based on Riskesdas from 2013 to 2018 the prevalence of Diabetes Mellitus (DM) increased from 6.9 percent to 8.5 percent which means around 22.9 millions of the prevalence of Diabetes Mellitus (DM). Diabetes mellitus is the most common cause of death in Indonesia. There is an increasing trend in the prevalence of this disease from year to year. Currently there are many drugs to cure the disease but this disease causes complications that are not easy to be controlled (Parisa, 2016).

There have been many treatments tried to cure diabetes, especially type 2 diabetes which is due to insulin deficiency 
or insulin resistance because the insulin receptors in the visceral adipose tissue decrease or their structure changes as a result of not responding to insulin. Starting from seeing a doctor, using herbal medicines, and trying various replacement treatments. The treatment with chemicals certainly has many side effects and negative effects. What can be done now is not only carrying out preventive measures such as regular exercise, drinking lots of water, reducing the intake of those with high glucose content and also carrying out curative actions through herbal treatments (Sampath et al., 2012). Generally, the use of conventional medicine is estimated to be more comfortable than the use of modern medicine. It is since the conventional medicine has fewer side effects than modern medicine (Patel \& Goyal, 2012). However, accuracy in using conventional drugs is still needed to minimize side effects, namely: correct drug, correct dose, correct time of use, correct method of use, not misused, and the right choice of drugs for special diseases (Dewi et al., 2019).

Ngokilo plant is a shrub with soft stems belonging to the genus Acanthaceae. It has thick, long-rounded and slightly hairy leaves with jagged edges. Ngokilo is included in the vile glass plant which contains high potassium in the leaves, as a result it is believed to be able to smooth urine and destroy stones in the bile, kidney and bladder. In the matter of curing diabetes, this plant has not been studied much, as a result it has not been known yet that its content is trusted by the public to treat diabetes. As a diabetes medicine, people generally use 3 fresh leaves to consume as fresh vegetables (Sulaeman, 2017).

Diabetes is a disease that is very risky and feared, so many alternative treatments are carried out (Care, 2015). In the traditional way, ngokilo plant has considerable efficacy in treating diabetes, therefore it is very significant to conduct a research on the ability of ethanol extract from Ngokilo leaves (Stachytarpheta mutabilis. Vahl) to lower the blood glucose content in mice.

\section{MATERIALS AND METHODS}

This research was carried out in June to August 2019. Sampling of ngokilo leaves in Jagran Village, Karanggeneng District, Lamongan Regency. The extract making and the treatments were carried out at the Environmental Health Laboratory of the Environmental Health Study Program, Faculty of Health Sciences, Lamongan Islamic University.

This research method was experimental, a method implemented to reveal the causal relationship between two or more variables by controlling the influence of other variables. This method 
was done by deliberately giving independent variables to the object of a research to determine the response in the dependent variable. Research used Ngokilo leaves which were used as an extract to treat type 2 diabetes mellitus.

\section{Research procedure}

Making Ngokilo leaf extract by maceration method by adding ethanol solution for 24 hours (Sutopo et al,, 2017). It stirred every 2 hours. Then filtered with a funnel padded a filter paper and then evaporated at a temperature of $800 \mathrm{C}$ with a rorati speed of $35 \mathrm{rpm}$ for 30 minutes and the results were taken in the form of Ngokilo leaf extract.

Increasing the blood glucose levels (hyperglycemia) in mice (Mus musculus) by intraperitonial injection using alloxan monohydrate at a dose of $175 \mathrm{mg} / \mathrm{kg}$ with an injection volume of $0.5 \mathrm{ml} / \mathrm{kg}$ as many as 2 times.

Application of Ngokilo leaf extract to Swiss Webster male mice aged approximately 2-3 months.

Checking blood sugardone by glucometer kit (Cahyaningrum et al., 2019).

\section{Tools and Materials}

The tools used are scales, $\mathrm{pH}$ meter, measuring cup, knife, filter paper, blender, dropper, stirring rod, infusion pan, cylinder vessel, filter, plastic, petri dish, measuring cup, enlemeyer tube, funnel, filter paper, weighing scale. Bunsen analytic, tongs, horn spoon, mouse cage, injection spluit, blood sugar checker, mice food containers, cotton wool, tissue. Ngokilo leaves. Aquades, ethanol liquid, $\mathrm{NaCl}$, Alloxan.

\section{Data Collection and Analysis}

\section{Techniques}

Data were collected by observing blood sugar levels before and after being given treatments.

Data analysis was performed using one way ANOVA with an alpha of $0.05 \%$. This analysis aimed at determining the difference in the effect of giving Ngokilo leaf extract in each treatment. Then the Least Significant Differences (LSD) test with alpha $0.05 \%$ was performed which aimed at seeing the differences in each treatment that can reduce blood sugar levels in mice.

\section{RESULTS AND DISCUSSION}

\section{Ngokilo Leaf Extract Dosage Formulation (Stachytarpheta mutabilis. Vahl)}

The doses of Ngokilo leaf extract given to mice were adjusted their body weight. The test mice were male, Swiss Webster, aged 2-3 months and weighing 30-40 grams. The ratio used in this treatment is $0: 1: 20: 40: 60$ 
In this study, the ethanol extract of the leaves of Ngokilo was given orally, so that $1 \%$ of the extract was used. The calculation formula is Dose Volume $=$ Weight of Mice $\mathrm{x}$ Percent of Feeding.

Based on (Kustini, 2019b) The treatment were carried out on mice were as follows: Group A: given distilled water 1 $\mathrm{ml} / 100$ gBB, Group B: given an extract dose of $11,25 \mathrm{mg} / 100 \mathrm{gBB}$ in $1 \mathrm{ml} / 100 \mathrm{gBB}$, Group C: extract dose $112.5 \mathrm{mg} / 100 \mathrm{gBB}$ in $1 \mathrm{ml} / 100 \mathrm{gBB}$ and Group D: extract dose of $337.5 \mathrm{mg} / 100 \mathrm{gBB}$ in $1 \mathrm{ml} / 100 \mathrm{gBB}$.

The doses formulation of Ngokilo leaf ethanol extract can be seen in table 1 as follows.

Table 1. The Doses Formulation of Ngokilo Leaf Ethanol Extract (Stachytarpheta mutabilis. Vahl)

\begin{tabular}{ccc}
\hline Treatment & Dose & Number of mice \\
\hline K & $0.4 \mathrm{ml}$ distilled water & 5 \\
P1 & $4.5 \mathrm{mg}$ / 40 grBB at 0.4 distilled water & 5 \\
P20 & $90 \mathrm{mg} / 40$ grBB at 0.4 distilled water & 5 \\
P40 & $180 \mathrm{mg} / 40$ grBB at 0.4 distilled water & 5 \\
P60 & $240 \mathrm{mg} / 40$ grBB at 0.4 distilled water & 5 \\
\hline
\end{tabular}

Table 1 shows that the treatments used are doses of 4.5, 90, 180 and 240 $\mathrm{mg} / 40 \mathrm{grBB}$, it is expected to provide a real picture of the effect of Ngoliko leaf extract to lower the blood sugar in mice.

In Table 1, it can be seen that the different doses of ngokilo leaf extract will be given to mice according to treatment.
Each treatment was repeated 5 times, namely 5 mice.

\section{Application of Ngokilo Leaf Extract}

The value of the average blood sugar levels of alloxan-induced diabetes mellitus mice after giving ethanol extract of Ngokilo leaves (Stachytarpheta mutabilis. Vahl) within 7 days is presented in table 2 .

Table 2. Lowering the glucose levels of Swiss Webster strains Male Mice Diabetes mellitus (Musmusculus) Induced by Alloxan in 8 (eight) treatment groups

\begin{tabular}{ccccc}
\hline $\begin{array}{c}\text { Treatment } \\
\text { Groups }\end{array}$ & $\begin{array}{c}\text { Initial } \\
\text { Glucose } \\
\text { Levels (mg / } \\
\text { dl) }\end{array}$ & $\begin{array}{c}\text { Glucose Levels Before } \\
\text { Treatments (mg / dl) }\end{array}$ & $\begin{array}{c}\text { Glucose Levels After } \\
\text { Treatment (mg / dl) }\end{array}$ & Difference \\
\hline K & 100.4 & 100.2 & 100.4 & \\
P1 & 107 & 147.8 & 145.2 & 2,6 \\
P20 & 103.4 & 149.6 & 132.2 & 17.4 \\
P40 & 96.6 & 136.8 & 100.6 & 36.2 \\
P60 & 96.4 & 140.6 & 83.4 & 57.2 \\
\hline
\end{tabular}


In table 2, it is explained that the average value of blood sugar levels of diabetes mellitus mice that induced by alloxan after giving ethanol extract of Ngokilo leaves (Stachytarpheta mutabilis. Vahl) for 7 days, there was a significant decrease in each treatment compared to the control. The lowest decrease in blood glucose levels in mice was in the P1 group, namely the treatment by giving the ethanol extract of leaves of ngokilo doses 4.5 $\mathrm{mg} / 40 \mathrm{grBB}$ at 0.4 distilled water, that is, there was a decrease in blood sugar levels by 147.8 to $145.2 \mathrm{mg} / \mathrm{dl}$, in the P20 group a dose of $90 \mathrm{mg} / 40 \mathrm{grBB}$ at 0.4 distilled water there was a decrease in blood sugar levels from $149.6 \mathrm{mg} / \mathrm{db}$ so $132.2 \mathrm{mg} / \mathrm{dl}$, group $\mathrm{P} 40$ dose $180 \mathrm{mg} / 40 \mathrm{grBB}$ in 0.4 distilled water there was a decrease in blood sugar levels from $136.8 \mathrm{mg} / \mathrm{dl}$ to $100.6 \mathrm{mg} / \mathrm{dl}, \mathrm{P} 60$ group dose of $240 \mathrm{mg} / 40$ grBB in 0.4 aquades contained decreased blood sugar levels from $140.6 \mathrm{mg} / \mathrm{dl}$ to 83.4 $\mathrm{mg} / \mathrm{dl}$. The control group that was given distilled water as much as $0.4 \mathrm{cc}$ had a slight increase in blood sugar levels.

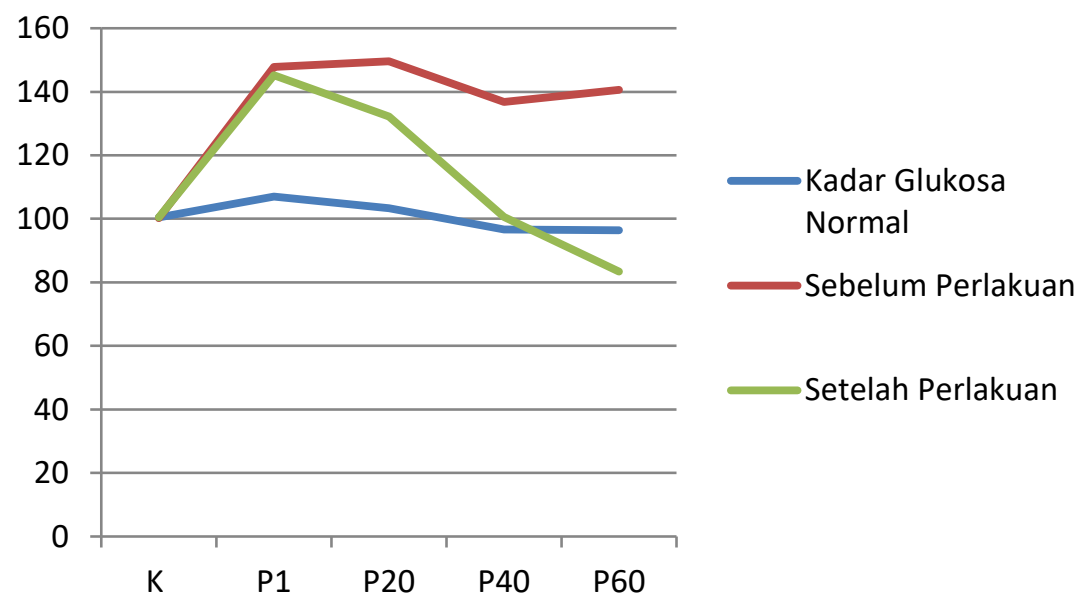

Figure 1. Comparison of blood sugar levels before and after treatment

From Figure 1 above, it is explained that the biggest difference between blood glucose levels is at P60, the fourth treatment used a dose of $240 \mathrm{mg} / 40 \mathrm{grBB}$ mice. It can be interpreted that in larger doses it contains an active compound that has a higher level so that it can prevent higher blood glucose levels from rising. It is in accordance with the research that single doses of 100,150 and $200 \mathrm{mg} / \mathrm{kgBB}$ of the leaf extract of Sambung Hidup leaves given can reduce blood sugar levels in mice. The decrease in blood sugar levels was assummed caused by the endogenous factors of each white mice which had individual characteristics and was heavily influenced by some non-physical and environmental factors. The fate of the drug, given Ngokilo leaf extract as a positive control, can be influenced by the pathological factors that can make the drug go down or rise. Decrease the effect of the 
drug was assumed as result of poor ultrastructure in the sequence until absorption in the gastrointestinal tract, necrotic cell death occurs. The results of blood vessels or increased excretion the study, when compared with the glucose through the kidneys (Nurhidayah, 2015). level of the negative control group, it

Based on (Cahyaningrum et al., 2019; showed that all treatment groups increased Simanjuntak, 2018) states that the their blood sugar levels, namely in the destruction of insulin-producing range of more than $200 \mathrm{mg} / \mathrm{dL}$, where the pancreatic $\beta$ cells is due to alloxan which is normal blood glucose levels of mice were an oxygen-derived pyrimidine derivative. around $62.8 \mathrm{mg} / \mathrm{dL}$ to $176 \mathrm{mg} / \mathrm{dL}$.

Alloxan can induce a multiphase blood Furthermore, the one way ANOVA glucose response when injected into the test was carried out to determine whether experimental animals, followed by changes there was a significance level of blood in plasma insulin concentrations and sugar using different treatment doses. accompanied by changes in $\beta$ cell

Table 3. ANOVA test results on the difference in concentration between treatments

\begin{tabular}{cccccc}
\hline & $\begin{array}{c}\text { Sum of } \\
\text { Squares }\end{array}$ & Df & $\begin{array}{c}\text { Mean } \\
\text { Square }\end{array}$ & F & Sig. \\
\cline { 2 - 6 } Between & 12960,560 & 4 & 3240,140 & 27,033 & .000 \\
$\quad \begin{array}{c}\text { Groups } \\
\text { Within Groups }\end{array}$ & 2397,200 & 20 & 119,860 & & \\
$\quad$ Total & 15357,760 & 24 & & & \\
\hline
\end{tabular}

Based on table 3, the results of the The follow-up test was carried out One Way ANAVA test show that the F count using a paired $\mathrm{T}$ test to see any differences is 27,033 greater than the $\mathrm{F}$ table, which is in blood sugar levels between before and 2.60. it means that there is a significant after treatment difference in blood sugar levels of mice in each treatment.

Table 4. Paired T Test Results for Differences Before and After Treatment

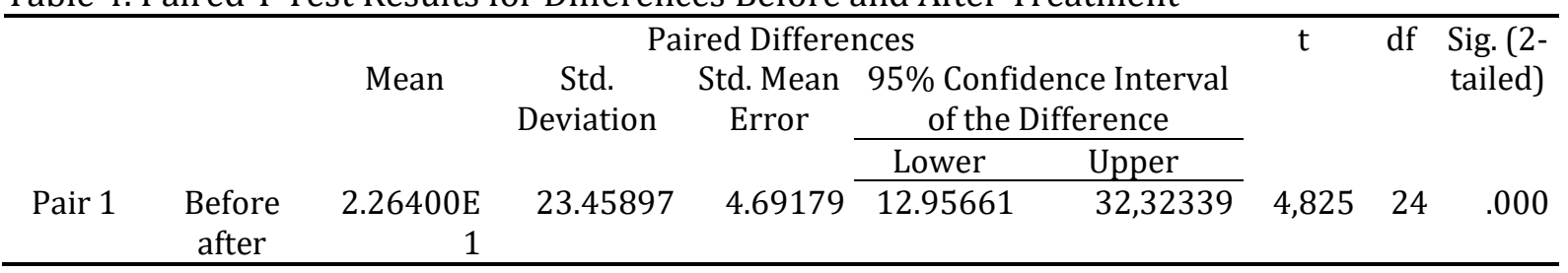


In table 4 it is explained that the results of the Paired T Test show that the $\mathrm{T}$ Count is $4,825>$ than the $\mathrm{T}$ Table of 1.71 . It showed that there was a significance level of glucose in mice between before and after treatment. The ethanol extract of Ngokilo leaves showed an effect on lowering blood sugar in diabetes mellitus-induced mice by alloxan.

According to research (Kustini, 2019a) which stated that there was a significant difference in blood sugar levels before and after the treatment. The administration of an ethanol extract of Ngokilo leaves showed a significant effect on lowering blood sugar in alloxan-induced diabetes mellitus mice.

The lowering blood sugar levels in diabetic mice that had been induced by alloxan after presenting ethanol extract of Ngokilo leaves was due to ethanol extract of Ngokilo leaves which had an astringent function, namely could emphasize intestinal mucous membrane protein and create a protective layer of the intestine, so that it prevented sugar intake so the blood glucose did not increase very highly, in addition it is also able to accelerate the discharge of blood, by speeding up the circulation related to the performance of the heart and by speeding up filtration and excretion of the kidneys so that there is an increase in urine production, the rate of excretion of glucose through the kidneys increases, resulting in a decrease in glucose levels in blood. Accelerate the release of glucose by increasing metabolism or entering into fat deposits. The pancreas is involved in this process to make insulin (Widowati, 2018; Dasopang, 2018).

As research conducted by (Cahyaningrum et al., 2019) that degenerative diseases such as diabetes mellitus can be prevented through ingredients that have antioxidant activity. Plants contain many natural flavonoids, and one of the functions of flavonoids is to prevent diabetes and its complications. The presence of flavonoids in amla (Phyllanthus emblica $\mathrm{L}$ ) is estimated to have potential as an antidiabetic. Research by (Widowati, 2018) stated that the provision of antioxidant compounds can ward off free radicals so that oxidative stress in diabetes mellitus can be reduced. Which in vitro the flavonoid compound has been proven to be a natural antioxidant that can trap free radicals.

The leaf extract also contains alkaloid and flavonoid compounds which have antioxidant properties that can suppress free radical activity. Flavonoids worked by inhibiting the enzymes alpha amylase and alpha glucosidase which were useful in breaking down carbohydrates into monosaccharides that can be absorbed by the intestine. Therefore, blood glucose levels do not rise after eating food or drinks 
with sugar or compounds that can be broken down into sugar. This effect is estimated to reduce blood sugar levels in people with diabetes mellitus(Soelistijo et al., 2015; Novita et al., 2020).

\section{CONCLUSION}

From the experiment on the potential of Ngokilo leaf ethanol extract on reducing blood glucose levels in white mice, it can be concluded that the ethanol extract of Ngokilo leaves was able to lower blood sugar levels in white mice. For 4 treatment doses, the best was P60, that was, with an initial glucose level of 140.6 $\mathrm{mg} / \mathrm{dl}$ to $83.4 \mathrm{mg} / \mathrm{dl}$.

\section{ACKNOWLEDGEMENT}

Thank you to the DPRM (Directorate of Research and Community Service) Kemenristekdikti for giving our team the opportunity to conduct research through the provision of Research Grants for Beginner Lecturer Research Schemes.

\section{REFERENCES}

Agung Alit Suka Astini, D. A., Gunawan, H. A., Wirono Aman Santoso, R. M., Andajani, S., \& Basori, A. (2017). the Effect of Soursop Leaf Extract on Pancreatic Beta Cell Count and Fasting Blood Glucose in Male Wistar Rats Exposed To a High-Fat Diet and Streptozotocin. Folia Medica Indonesiana, 53(1), 12 https://doi.org/10.20473/fmi.v53i1.5484
Cahyaningrum, Putu Lakustini ; Yuliari, Sang Ayu Made; Suta, I. B. P. (2019). Uji Aktivitas Antidiabetes Dengan Ekstrak Buah Amla (Phyllanthus Emblica L) Pada Mencit Balb/C Yang Di Induksi Aloksan. Journal of Vocational Health Studies, 03(01), 6-10. https://doi.org/10.20473/jvhs.V3I2.2019.53

Care, F. (2015). Introduction. Diabetes Care, 38(January), S1-S2. https://doi.org/10.2337/dc15-Soo1

Dasopang, E.S. (2018), Karakteristik Pengetahuan Dan Kepatuhan Diet Pada Penderita Diabetes Mellitus DiPuskesmas Pekan Labuhan Medan, Talenta Conference Series: Tropical Medicine (TM) (2018) 1(3) 038-045.

Dewi, A. P., Wardaniati, I., Pratiwi, D., \& Valzon, M. (2019). Sosiologi Gerakan Masyarakat Cerdas Menggunakan Obat Di Desa Kumain Kecamatan Tsndun Kabupaten Rokan HuluHulu, Sosiologi Gerakan Masyarakat Cerdas Menggunakan Obat Di Desa Kumain Kecamatan Tsndun Kabupaten Rokan. Psikologi Perkembangan, 2(2), 135.

Dewi, I. P. (2009). Identifikasi Drug Related Problems (Drps) Kategori Obat Salah Dan Reaksi Obat Yang Merugikan Pasien Diabetes Mellitus Tipe 2 Di Instalasi Rawat Inap Rumah Sakit Umum Daerah Wonogiri Tahun 2007 [Universitas Muhammadiyah Surakarta].

Forouzanfar, M. H., Afshin, A., Alexander, L. T., Biryukov, S., Brauer, M., Cercy, K., Charlson, F. J., Cohen, A. J., Dandona, L., Estep, K., Ferrari, A. J., Frostad, J. J., Fullman, N., Godwin, W. W., Griswold, M., Hay, S. I., Kyu, H. H., Larson, H. J., Lim, S. S., ... Zhu, J. (2016). Global, regional, and national comparative risk assessment of 79 behavioural, environmental and occupational, and metabolic risks or clusters of risks, 1990-2015: a systematic analysis for the Global Burden of Disease Study 2015. The Lancet, 388(10053), 1659-1724. https://doi.org/10.1016/So140-6736(16)316798

Hasanah, R. U. R., Sundhani, E., \& Nurulita, N. A. (2017).. Effect Of Ethanolic Extract Of Annona muricata L Seeds Powder To Decrease Blood Glucose Level Of Wistar 
Male Rats With Glucose Preload Proceeding ICMHS 2016, o(o), 112-115.

Kustini, I. S. (2019a). Pengaruh Ekstrak Daun Ngokilo (Stachytarpheta mutabilis, Vahl ) Terhadap Penyakit Diabetes mellitus. Journal of Pharmaceutical Care Anwar Medika (J-PhAM, 7(2), 28-35. http://jurnal.stikesrsanwarmedika.ac.id/ind ex.php/jpcam/article/view/10

Kustini, I. S. (2019b). Upaya Mengatasi Penyakit Diabetes Mellitus Melalui Pemanfatan Ekstrak Daun Ngokilo. Prosiding SnasPPM UNIROW, 100-106.

Novita, D., Nugrahalia, M., \& Fauziah, I. (2020). Hubungan Antara kadar Vitamin D dengan HbAic pada Pasien Diabetes Mellitus Tipe 2 di Laboratorium Klinik Thamrin Medan Tahun 2019. Jurnal Ilmiah Biologi UMA (JIBIOMA), 2(1), 8-12.

Nurhidayah, K. (2015). Potensi Ekstrak Daun Keji Beling Sebagai Penurun Kadar Glukosa Darah: Uji In Vivo Pada Tikus. Prosiding Seminar Nasional Kefarmasian Ke-2, 24-25.

Parisa, N. (2016). Efek Ekstrak Daun Salam pada Kadar Glukosa Darah The Effect of Bay Leaves on Blood Glucose Levels. JK Unila, 1, 404-408.

Patel, S. S., \& Goyal, R. K. (2012). Emblica officinalis geart.: A comprehensive review on phytochemistry, pharmacology and ethnomedicinal uses. In Research Journal of Medicinal Plant (Vol. 6, Issue 1, pp. 6-16). https://doi.org/10.3923/rjmp.2012.6.16

Rahmawati, S., Rifqiyati, N., Biologi Saintek UIN Sunan Kalijaga Yogyakarta, M. F., \& Biologi UIN Sunan Kalijaga Yogyakarta, D. (2014). Efektivitas Ekstrak Kulit Batang, Akar, Dan Daun Sirsak (Annona muricata L) Terhadap Kadar Glukosa Darah. Oktober, 1435(2), 8191.

Rohilla, A., \& Ali, S. (2012). Alloxan Induced Diabetes: Mechanisms and Effects. International Journal of Research in Pharmaceutical and Biomedical Science, 3(2), 819-823.

Sampath Kumar, K. P., Bhowmik, D., Dutta, A., Yadav, A. P., Paswan, S., Srivastava, S., \& Deb, L. (2012). Recent Trends in Potential
Traditional Indian Herbs Emblica Officinalis and Its Medicinal Importance. Journal of Pharmacognosy and Phytochemistry, 1(1), 24-32.

Sangala, R., Kodati, D., Burra, S., Gopu, J., \& Dubasi, A. (2011). Evaluation of Antidiabetic Activity of Annona Squamosa Linn Seed in Alloxan Induced Diabetic Rats. 2(2), 100-106.

Simanjuntak, H. (2018). Pemanfaatan Tumbuhan Obat Diabetes Mellitus Di Masyarakat Etnis Simalungun Kabupaten Simalungun Provinsi Sumatera Utara. BIOLINK : Jurnal Biologi Lingkungan Industri Kesehatan, 5(1), 59-70.

Soelistijo, S., Novida, H., Rudijanto, A., Soewondo, P., Suastika, K., Manaf, A., Sanusi, H., Lindarto, D., Shahab, A., Pramono, B., Langi, Y., Purnamasari, D., \& Soetedjo, N. (2015). Konsesus Pengelolaan Dan Pencegahan Diabetes Melitus Tipez Di Indonesia 2015. In Perkeni.

https://www.google.com/url?sa=t\&source= web\&rct=j\&url=https://pbperkeni.or.id/wpcontent/uploads/2019/o1/4.-KonsensusPengelolaan-dan-Pencegahan-Diabetesmelitus-tipe-2-di-Indonesia-PERKENI2015.pdf\&ved=2ahUKEwjy8KOs8cfoAhXCb3 oKHQbiCkoQFjADegQIBhAB\&usg=AOv

Sulaeman. (2017). Ngokilo, Tanaman Semak buat yang Berurusan dengan segala "Batu" dalam Organ Tubuh. https://intisari.grid.id/read/o399138/ngokil o-tanaman-semak-buat-yang-berurusandengan-segala-batu-dalam-organtubuh?page=all

Sutopo, T., Bestari, R. S., \& Sintowati, R. (2017). Uji Ekstrak Etanol 70\% Daun Sirih (Piper betle L.) Terhadap Bleeding Time Pada Mencit Jantan Galur Swiss Webster. Biomedika, $8(2)$.

https://doi.org/10.23917/biomedika.v8i2.291 7

Widowati, W. (2018). Potensi Antioksidan sebagai Antidiabetes. JKM, 7(02), 1-11.

Zamri, A. (2019). Diagnosis dan Penatalaksanaan Hyperosmolar Hyperglycemic State (HHS). Jmj, 7(2), 151-16o. 